\title{
CONFIRMED OCCURRENCE AND NEW RECORDS OF SCIOTA RHENELLA (ZINCKEN, 1818) (LEPIDOPTERA: PYRALOIDEA: PYRALIDAE) IN CROATIA
}

\section{Danijela Gumhalter}

Azuritweg 2, 70619 Stuttgart, Germany (E-mail: danijela.gumhalter@gmail.com)

Gumhalter, D.: Confirmed occurrence and new records of Sciota rhenella (Zincken, 1818) (Lepidoptera: Pyraloidea: Pyralidae) in Croatia. Nat. Croat., Vol. 30, No. 2, 417-423, Zagreb, 2021.

Three specimens of Sciota rhenella were recorded in July 2021 in Zagreb, northwestern Croatia. Although the species was previously mentioned in the literature for Croatia, its first finding was published without any given information on the locality and date of collection. As far as we know, the only published information on this species is that it is present in the fauna of Croatia.

This paper aims at presenting the first data on the localities and dates of collection of S. rhenella in Croatia. By the provision of new, reliable and evidence-based data, the occurrence of $S$. rhenella in the country is confirmed. Hereby, a contribution to the knowledge of the Croatian pyraloid moth fauna is also given.

Keywords: Sciota rhenella, Pyraloidea, Pyralidae, fauna, Zagreb, Croatia

Gumhalter, D.: Potvrđena prisutnost i novi nalazi vrste Sciota rhenella (Zincken, 1818) (Lepidoptera: Pyraloidea: Pyralidae) za Hrvatsku. Nat. Croat., Vol. 30, No. 2, 417-423, Zagreb, 2021.

Tri primjerka vrste Sciota rhenella prikupljena su u srpnju 2021. godine u Zagrebu, u sjeverozapadnoj Hrvatskoj. Iako je vrsta prethodno bila navođena u literaturi za Hrvatsku, njen je prvi nalaz objavljen bez dodatnih podataka o lokalitetu i datumu njenog prikupljanja. Stoga je jedini objavljen podatak o ovoj vrsti taj da je ona prisutna u fauni Hrvatske.

U radu se navode prvi podaci o lokalitetima i datumima prikupljanja vrste S. rhenella u Hrvatskoj. Dajući nove pouzdane dokaze, prisutnost ove vrste $u$ fauni Hrvatske je potvrđena. Usto je dan prilog poznavanju hrvatskoj fauni Pyraloidea.

Ključne riječi: Sciota rhenella, Pyraloidea, Pyralidae, fauna, Zagreb, Hrvatska

\section{INTRODUCTION}

The superfamily Pyraloidea, comprising the families Crambidae and Pyralidae, currently includes over 15,576 described species worldwide (Nuss et al., 2003-2020).

The Croatian pyraloid moth fauna is very diverse. In total, it currently counts almost 400 species (Gumhalter, 2021). Nonetheless, more new species are regularly being added to the checklist (Koren, 2020, 2021a, 2021b; GumHalter, 2021), which shows that the fauna is still not completely known. The more it is studied in detail, the more additions can be expected in the future.

Although a Croatian species list exists (Gumhalter, 2019a, 2019b, 2021), there are still many knowledge gaps on the distribution and conservation status of many listed 
species. An example of such knowledge gaps is the occurrence of only historically recorded species whose presence is still to be reconfirmed and another is the distribution of species that have been recorded only once in recent investigation and are to be reported from more localities in the future. Besides, not all Croatian regions have been equally studied in the past. So, there is still missing information on the status or occurrence of many species from lesser-studied parts of Croatia. Throughout faunistic research, such knowledge gaps could be filled, which would help to define the status of the current Croatian pyraloid moth fauna.

To contribute to the knowledge of the overall Croatian pyraloid moth fauna, numerous field surveys were carried out in different parts of the country. In July 2021, the species Sciota rhenella was recorded from the northwestern parts of Croatia. These findings represent the second record of this species from Croatia, as its first occurrence was documented in a project report by Šššć-KLJAJO et al. (2016). However, the date and geographic area of its occurrence remained unknown, as the published report did not contain this information. As far as we know, the only published information on this species is that it is present in the fauna of Croatia.

In this paper, the first published localities of S. rhenella in Croatia are presented. The provision of new, reliable and evidence-based data confirms the occurrence of $S$. rhenella in the country and makes a contribution to the knowledge of the overall Croatian pyraloid moth fauna.

\section{MATERIALS AND METHODS}

On 30 July 2021 three specimens from the genus Sciota were caught in Zagreb, northwestern Croatia. The specimens were caught with a UV light on a meadow close to Lake Jarun (Fig. 1). The specimens were identified as S. rhenella (Fig. 2) from

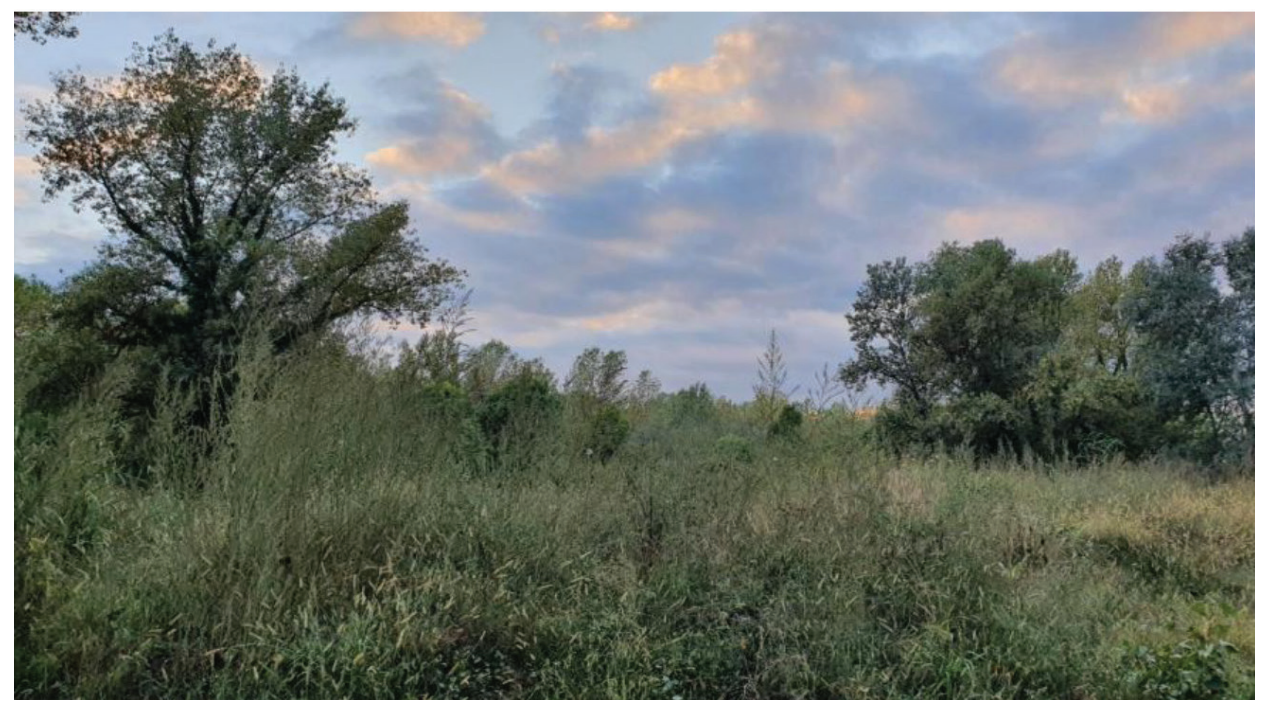

Fig. 1. The meadow close to Lake Jarun where the three specimens of S. rhenella were collected (photo: I. Štern). 


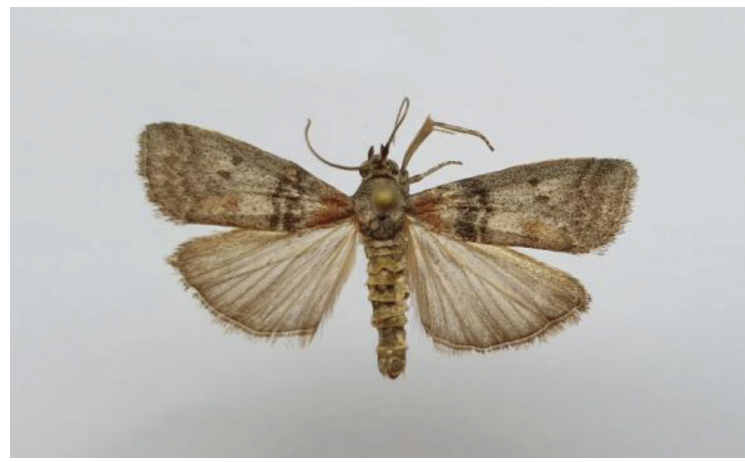

Fig. 2. A male specimen of S. rhenella (wingspan $22 \mathrm{~mm}$ ) collected on $30 \mathrm{July}, 2021$ in Zagreb (photo: D. Gumhalter).

the family Pyralidae. The determination of the species was conducted according to SLAmKa (2019). Dissections of genitalia were performed by the standard procedure and the genitalia slides are deposited together with the specimens in the author's private collection (coll. Gumhalter).

\section{RESULTS AND DISCUSSION}

Due to its geographic position across three biogeographic zones, Croatia has a great biological diversity. This applies especially if compared to the neighboring countries Austria, Hungary, Italy and Slovenia (GumhaLter, 2020). Currently, 396 Pyraloidea species have been reported from Croatia (Gumhalter, 2021).

Over the last two centuries, many papers were published on the butterfly and moth fauna of Croatia that also included Pyraloidea species (e.g. Mann, 1857, 1867, 1869; Rebel, 1891, 1895, 1903, 1904; Schawerda, 1921; Klimesch, 1942; etc.). However, the majority of these publications relate to the Croatian coast, which is an area very accessible for field surveys. However, little was published from inaccessible areas such as mountain ranges or some inland parts of the country (e.g. Mann, 1867; Rebel, 1895; Abafi-Aigner et al., 1896; 1903; KoČA, 1925, etc.). Therefore, not all Croatian regions have been equally studied in the past. According to Gumhalter (2019a), the best-studied part of Croatia is the Mediterranean biogeographic region, with $95 \%$ of all recorded pyraloid moth species occurring. Altogether $49 \%$ of all pyraloid moth species from Croatia have been recorded in the inland and only $31 \%$ in the mountainous biogeographic region. This indicates that the distribution and conservation status of pyraloid moths in the least studied biogeographic zones is insufficiently known. All three biogeographic zones are shown in Fig. 3.

The author frequently carries out research on the pyraloid moth fauna of Croatia. This long-term study started in 2016 and is still being carried out, including in inland Croatia. The results of these surveys contribute to the knowledge of the overall pyraloid moth fauna of Croatia (GumHalter, 2021; Gumhalter et al., 2018), especially of the least-studied inland and mountainous biogeographic zones (GuMHALTER et al., 2020; GUMHALTER \& KuČINIĆ, 2020, 2021). 


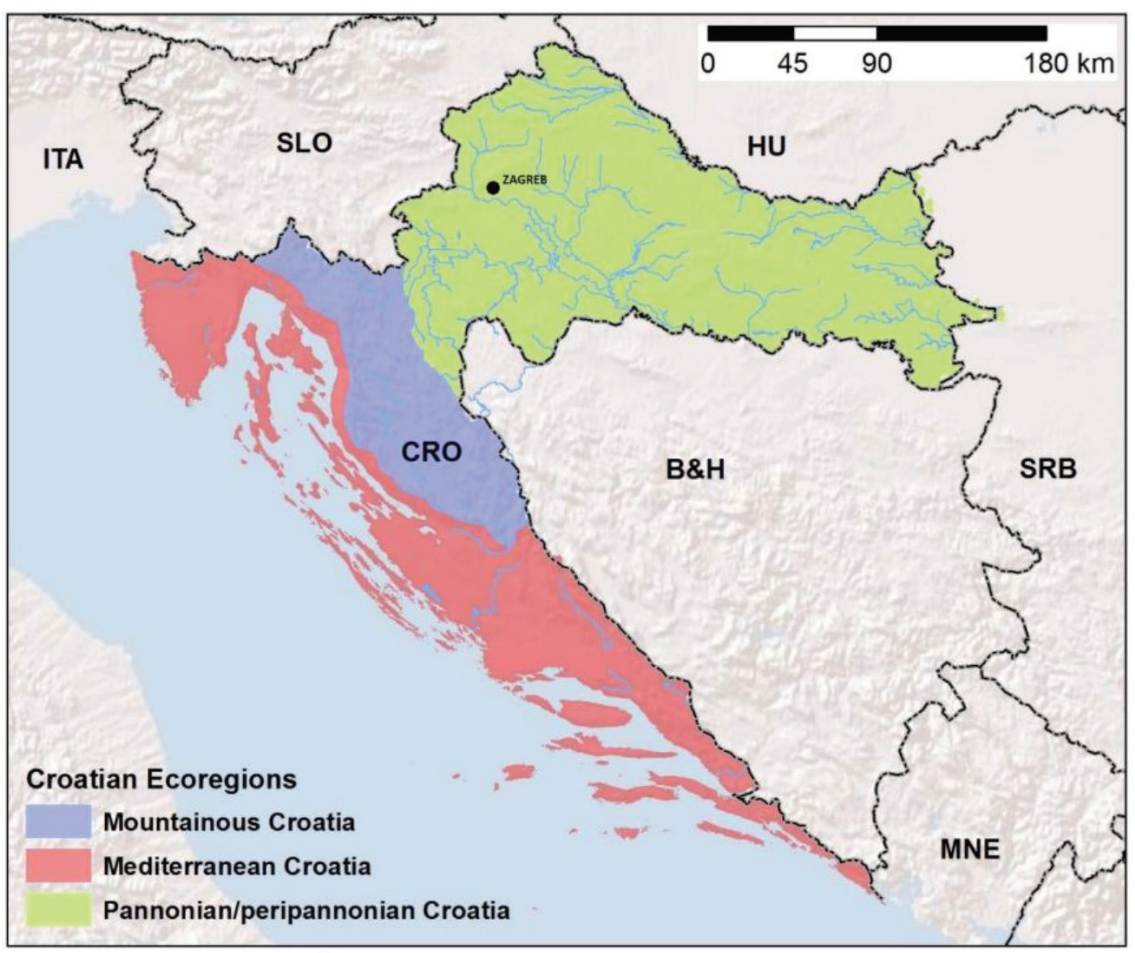

Fig. 3. Map showing the position of the collecting site Zagreb in Croatia and all three biogeographic zones (Ecoregions).

During a moth survey carried out in inland Croatia in July 2021, the species $S$. rhenella was recorded. The current findings from the northwestern parts of the country represent the second set of records of this species from the Croatian territory. The first occurrence of $S$. rhenella in Croatia was documented in a project report by Šššć-KLJAJO et al. (2016). This publication deals with the results from the biggest inventory project on the Croatian fauna. In this final project report, which is available only in Croatian, all the collected species are listed without being analyzed. Therefore, no details on the locality or the date of collection were given. One of the mentioned species in the project report is S. rhenella from the family Pyralidae. As the project was not aiming at providing additional information on the recorded species, the date and geographic area of its occurrence in Croatia remained unknown. There are no other published research data that deal with this species in Croatia and as far as we know, the only published information on this species is only that it is present in the fauna of Croatia.

To provide more information on the occurrence of $S$. rhenella in Croatia, the author has requested all available data on this species from the corresponding author of the inventory project on the Croatian fauna. The shared project results revealed that $S$. rhenella was recorded several times in 2015, in the region of Slavonia in the east of the country: 16.07.2015 (Tenja), 21.07.2015 (Mirkovački pašnjak) and 22.07.2015 (Zmajevac). These first findings from Slavonia, added to the above presented findings from Zagreb, are the first available information on the species` distribution in Croatia. 
According to Slamka (2019), S. rhenella is common in flood plains around poplars, from lower altitudes to mountainous areas. The greenish larvae live from June until October between two or more leaves spun together. Host plants are poplars, mainly: Populus nigra, P. tremula, P. canadensis, P. alba, P. deltoides and Salix sp. Pupation occurs on the ground leaves and the moth flies in two or more generations from April until September. The imago has a wingspan from 20 up to $27 \mathrm{~mm}$. The species S. rhenella is distributed from Portugal through the middle belt of Europe to Russia, Kazakhstan and Turkmenistan. It is also known from Turkey, Syria and Iraq.

Slamka (2019) states, that the species is similar to S. hostilis, S. adelphella and S. elegiella. The species S. hostilis is generally smaller than S. rhenella (SLAmkA, 2019) and was not previously reported from Croatia (Gumhalter, 2021). The species S. elegiella is distributed only in southern Spain, Portugal, Algeria and northern Morocco (Slamka, 2019). Although S. adelphella is reported from Croatia (Gumhalter, 2021), the species has different coloration (SLAMKA, 2019) and can also be differentiated from $S$. rhenella by examination of the genitalia. Such an analysis was done and the correct determination of $S$. rhenella was confirmed.

The three specimens were caught in northwestern Croatia, on a meadow close to

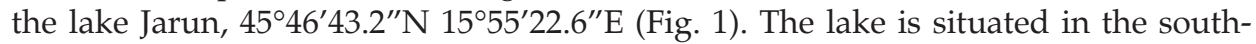
western part of the city of Zagreb, at an altitude of 115 meters.

Jarun Recreational and Sports Centre is an urban environment. Such environments include specific habitats exposed to human pressure often characterized with higher disturbance and nitrogen availability, preferred by 'special' groups of plants such as weeds, ruderal plants, and invasive plants (KoJIĆ \& ŠINŽAR, 1985; PYšEK et al., 2010).

According to Vuković et al. (2013), the area of Jarun Recreational and Sports Centre comprises artificial lakes, islands and land with natural and artificial cover. The complex is surrounded by residential districts, except in the south, where the main flow of the River Sava with its embankment represents the border onto more southern areas. The authors further state, that the area is climazonally situated in the zone of oak-hornbeam forests and that the main determinant of its natural vegetation is the level of underground and flood water. The main vegetation of the Sava River floodplain before intensive human influence were pedunculate oak forests, together with willow, alder and poplar forests (HoRvaTić, 1967; Vukelić, 2012). The northern parts are more urban, gradually turning into more natural forms towards the south. The most authentic area is the south-eastern part, where no human intervention is allowed (Vuković et al., 2013). This area lies close to the meadow, where the moths were caught. The meadow is surrounded by hostplants from the family Salicaceae and covered by weeds (Fig. 1). As mentioned by Vuković et al. (2013) the following poplar and willow species can be found in the lake Jarun area: Populus alba, P. nigra, P. tremula, Salix alba, S. eleagnos, S. fragilis, S. purpurea and S. triandra.

With this information, the occurrence of the species in Croatia is confirmed and the first data on its locality and date of collection are now available. These new data represent a source of more reliable and evidence-based information on the occurrence of S. rhenella in Croatia and contribute to the knowledge of the Pyraloidea fauna from inland Croatia, as well as to the overall Croatian pyraloid moth fauna.

Although the knowledge of the pyraloid moth species occurring in Croatia has been increasing over the last two decades, some geographic areas and the distribu- 
tion of many species remain poorly studied. Additions to the knowledge of the Croatian Pyraloidea should be made not only by supplementing the species list. Future faunistic research should also be focused on surveys whose results would help in filling all the existing knowledge gaps. The findings of previously only historically recorded species should be reconfirmed in future studies, as a long-term goal could also be the definition of the status of the current Croatian pyraloid moth fauna or the current fauna of specific geographic regions.

\section{ACKNOWLEDGEMENTS}

The author is grateful to Martina Šašić from the Croatian Natural History Museum in Zagreb for sharing the data on the first occurrence of $S$. rhenella from the inventory project on the Croatian fauna. The author is also grateful as to František Slamka for confirming the identification of S. rhenella and to Ivan Štern for providing the photo of the collecting site.

Received August 25, 2021

\section{REFERENCES}

Abafi-Aigner, L., Pavel, J. \& Uhryk, F., 1896: Fauna Regni Hungariae. Lepidoptera. Regia Societas Scientiarum Naturalium Hungarica, Budapest, $82 \mathrm{pp}$.

Abafi-Aigner, L., 1903: Adálek Microlepidopteráink ismeretéhez. Rovartani lapok 10 (7), $133-137$.

Gumhalter, D., 2019a: First checklist of pyraloid moths (Lepidoptera: Pyraloidea) in Croatia. Zootaxa 4604 (1), 059-102. https:/ / doi.org/10.11646/zootaxa.4604.1.3

Gumhalter, D., 2019b: A revised checklist of pyraloid moths (Lepidoptera: Pyraloidea) in Croatia. Natura Croatica 28 (2), 271-288. DOI: 10.20302/NC.2019.28.20

Gumhalter, D., 2020: Biodiversity, ecological and biogeographical features of Pyralidae and Crambidae (Insecta, Lepidoptera) in three Croatian climate regions. PhD Dissertation, University of Zagreb, Zagreb, 369 pp. (in Croatian).

Gumhalter, D., 2021. Psorosa mediterranella (Amsel, 1954) (Lepidoptera: Pyralidae) - A new species for the Croatian Pyraloid moth fauna, with an updated checklist. Natura Croatica 30 (1), 37-52. https:/ / doi.org/10.20302/NC.2021.30.4

Gumhalter, D., Kučinić, M., Vajdić, M., Perović, F., Pelić-Fixa, D. \& Lukač, G., 2018: New records of the crambid moth Euclasta splendidalis (Herrich-Schäffer, [1848]) (Lepidoptera: Crambidae) in Croatia with notes on Pyraloidea fauna from the Neretva Valley. Natura Croatica 27 (1), $225-232$. https://doi.org/10.20302/NC.2018.27.12

Gumhalter, D., Kučinić, M. \& ŠAŠıć, M., 2020. Data on pyraloid moth specimens (Lepidoptera: Pyraloidea) held in the collections of CNHM in Zagreb, Croatia. Zootaxa 4895 (1), 037-066. https:// doi.org/10.11646/zootaxa.4895.1.2

Gumhalter, D. \& Kučinić, M., 2020: First published records of Catoptria acutangulellus (Herrich-Schäffer, 1847) (Lepidoptera: Crambidae) in Croatia after almost a century. Natura Croatica 29 (1), 129-134. DOI 10.20302/NC.2020.29.12

Gumhalter, D. \& Kučinić, M., 2021: Contribution to the knowledge of the Croatian Pyraloidea fauna. Species reported from Biokovo Natural Park (Insecta: Lepidoptera). SHILAP Revista de lepidopterología 49 (193), 65-83.

Horvatić, S., 1967: Fitogeografske značajke i raščlanjenje Jugoslavije. In: Horvatić, S. (ed.), Analitička flora Jugoslavije 1. Flora analytica Iugoslaviae 1. Šumarski fakultet Sveučilišta u Zagrebu, Zagreb.

Klimesch, J., 1942: Über Microlepidopteren-Ausbeuten von Zaton bei Gravosa (Süddalmatien) in Mitteilungen Münchener entomologischen Gesellschaft 32, 347-399, pl. 13-15.

KočA, GJ., 1925: Drugi prilog fauni leptira (Lepidoptera) Hrvatske i Slavonije. Glasnik hrvatskog prirodoslovnog društva 36 (1-2) (za god. 1924), 63-68. 
KoJIĆ, M. \& ŠINŽAR, B., 1985: Korovi. Naučna knjiga, Beograd.

Koren, T., 2020: Three montane grass moths (Lepidoptera: Crambidae) new to the fauna of Croatia. Acta Entomologica Serbica 25(1), 29-34. DOI: 10.5281/zenodo.3735368

Koren, T., 2021a: Dioryctria Robiniella (Millière, 1865) (Lepidoptera: Pyralidae) is a member of fauna of Croatia. Acta Entomologica Serbica 26 (1), X-XX. DOI: 10.5281/zenodo.4551159

Koren, T., 2021b: Further additions to the grass moth (Lepidoptera: Crambidae) fauna of Croatia. Natura Croatica 30 (1), 243-250. DOI: 10.20302/NC.2021.30.15

Mann, J., 1857: Verzeichnis der in Jahr 1853 in der Gegend von Fiume gesammelten Schmetterlinge. Wiener Entomologische Monatschrift 1 (6), 161-189 [170-173 for Pyraloidea].

MANN, J., 1867: Schmetterlinge gesammelt im J. 1866 um Josefsthal in der Croat. Militärgrenze. Verhandlungen der Zoologisch-Botanischen Gesellschaft Wien 17, 63-76.

ManN, J., 1869: Lepidopteren, gesammelt während dreier Reisen nach Dalmatien in den Jahren 1850, 1862, 1868. Verhandlungen des Zoologisch-Botanischen Gesellschaft in Wien 19, 371-388.

Nuss, M., Speidel, W. \& Segerer, A., 2013: Fauna Europaea: Pyralidae. In: Karsholt, O. \& Nieukerken, E. J. van, Fauna Europaea: Lepidoptera, Moths. Fauna Europaea version 2017.06, https://fauna-eu.org (Accessed 03 September 2021).

Pyšek, P., Chytrú, M. \& Jarošík, V., 2010: Habitats and land use as determinants of plant invasions in the temperate zone of Europe. In: Perrings, C., Moony, H. \& Williamson, M. (eds.), Bioinvasions and globalisation. Ecology, economics, management and policy. Oxford University Press, Oxford. p. 66-79.

Rebel, H., 1891: Beitrag zur Microlepidopteren-Fauna Dalmatiens. Verhandlungen der kaiserlich-königlichen zoologisch-botanischen Gesellschaft in Wien 41, 610-639.

Rebel, H., 1895: Verzeichniss der von Dr. R. Sturany im Jahre 1895 in Croatien gesammelten Lepidopteren. Verhandlungen der zoologisch-botanischen Gesellschaft in Wien 45, 390-392.

Rebel, H., 1903: Studien über die Lepidopterenfauna der Balkanländer. I. Teil. Bulgarien und Ostrumelien. Annalen des Naturhistorischen Museums in Wien 18, 123-347.

Rebel, H., 1904: Studien über die Lepidopterenfauna der Balkanländer. II. Teil. Bosnien und Herzegowina. Annalen des Naturhistorischen Museums in Wien 19, 97-377.

SCHAWERDA, K., 1921: Beiträge zur Lepidopterenfauna der kroatischen Küste und Neubeschreibungen. Deutsche Entomologische Zeitschrift Iris 35, 111-138.

Slamka, F., 2019: Pyraloidea of Europe (Lepidoptera). Phycitinae - Volumen 4, Part 1. Identification Distribution - Habitat - Biologie 4, František Slamka, Bratislava, 432 pp.

ŠAšıć-KLJAjO, M., 2016: Završno izvješće za skupinu Lepidoptera: 188-226, maps, figs. In: HaTić, D., Mrakovčić, M. \& Z. Mesić (Eds.), Projekt integracije u EU Natura 2000: Terensko istraživanje i laboratorijska analiza novoprikupljenih inventarizacijskih podataka za taksonomske skupine: Actinopterygii i Cephalaspidomorphi, Amphibia i Reptilia, Aves, Chiroptera, Decapoda, Lepidoptera, Odonata, Plecoptera, Trichoptera.

Vukelić, J., 2012: Šumska vegetacija Hrvatske. Šumarski fakultet Sveučilišta u Zagrebu i Državni zavod za zaštitu prirode, Zagreb.

Vuković, N., Boršıć, I., Župan, D., Alegro, A. \& Nikolić, T., 2013: Vascular flora of Jarun (Zagreb, Croatia). Natura Croatica 22 (2), 275-294. 